\title{
Улучшение убойных показателей цыплят-бройлеров за счет использования в их кормлении ферментного пробиотика
}

Калоев Б.С., доктор сельскохозяйственных наук, зав. кафедрой кормления, разведения и генетики сельскохозяйственных животных

ФГБОУ ВО «Горский государственный аграрный университет», г. Владикавказ

\begin{abstract}
Аннотация: Опыт по изучению Влияния ферментного пробиотика на мясные качества и,юплят-бройлеров был проведен на 4 группах бройлеров кросса Росс-308 (100 голов б каждой), быращиваемых до 42 дней жизни. Контрольная группа получала полнорационные комбикорма местного произбодства на основе зерна кукурузы, пшеницы, подсолнечного жмыха и соевого шрота (основной рацион). Птице опытных групп 1-3, 6 дополнение к основному рациону, 6 комбикорма добабляли разные дозы изучаемого фрерментного пробиотика $(0,5$, 1,0 и 1,5 к2/m корма соответственно). Полученные результаты подтверждают положительное влияние пробиотика на основные мясные качества подопытной птицы с ростом дозы препарата 6 рационах. Наилучшие показатели мясной продуктибности (предубойная жибая масса, масса полупотрошеной и потрошеной тушки, масса сьедобных частей тушки) были получены 6 группе 2, где они были достоверно быше, чем 6 контроле ( $P \geq 0,999) ;$ дальнейшее повышение уровня пробиотика до 1,5 кг/m не дало существенного улучшения изучаемых показателей по сравнению с этой группой, поэтому рациональной дозой его ввода б комбикорма для бройлеров рекомендовано считать 1,0 кг/m.
\end{abstract}

Ключебые слова: и,ьплята-бройлеры, ферментный пробиотик, убойная масса, убойный быход, категория тушек.

Введение. Птицеводство считается одной из самых эффективных отраслей животноводства, основной фактор которой - рациональное использование кормовых ресурсов при организации сбалансированного кормления птицы. Полноценное кормление птицы организуется с учетом особенностей переваривания пищи в желудочно-кишечном тракте, что также является одним из путей повышения мясной продуктивности $[2,5,7,8]$.

Основными кормами в птицеводстве являются злаковые и бобовые зерновые культуры. Помимо большого количества легкогидролизуемых питательных веществ, большинство из них содержит трудногидролизуемые вещества и ингибиторы, среди которых выделяются некрахмалистые полисахариды. Для их разрушения используются кормовые ферменты или их комплексы, под влиянием которых улучшается усвоение питательных веществ корма. Экзогенные ферменты, введенные в организм птицы в составе ферментных препаратов, расщепляя дополнительное количество питательных веществ корма, увеличивают его питательную ценность. Это, в свою очередь, способствует повышению продуктивности, улучшению качества продукции и снижению ее себестоимости $[1,3,10,11]$.

Не только ферментные препараты активно используются в кормлении птицы. Также широкое применение в птицеводстве находят различные микробиологические препараты, в особенности пробиотики, способствующие формированию нормальной (полезной) микрофлоры желудочно-кишечного тракта и сохранению здоровья птицы. Отдельными авторами отмечается положительное влияние пробиотиков на полноту переваривания питательных веществ и всасывание их в кишечнике.

Практическое использование в животноводстве пробиотических препаратов может осуществляться как в чистом виде, так и в сочетании с другими биологически активными веществами, например, с ферментами или витаминами. При этом проявляется синергизм их действия [4]. 
В последние годы проводится много исследований, связанных с разработкой технологий, в основе которых лежит совместное использование различных групп биологически активных веществ, для проявления большего эффекта при выращивании сельскохозяйственных животных и птицы. Изучение эффективности раздельного и совместного использования пробиотиков и ферментов при выращивании сельскохозяйственной птицы является весьма важным направлением [6,9].

Ферментные пробиотики - это добавки, содержащие одновременно экзогенные ферменты и пробиотические культуры, которые также выделяют собственные ферменты, участвующие в пищеварении в организме хозяина. Действие ферментативных пробиотиков заключается в снижении затрат на корма за счет повышения их усвояемости, подавлении развития патогенных микроорганизмов и формировании полезной микрофлоры в пищеварительном тракте. Их влияние на обменные процессы организма птицы нуждается в дополнительном изучении, поэтому исследования, направленные на решение обозначенной проблемы, являются весьма актуальными.

Исходя из вышеизложенного, целью проведенной работы явилось изучение воздействия различных доз ферментного пробиотика на отдельные показатели мясной продуктивности цыплятбройлеров.

Материал и методика исследований. Научно-производственный опыт был проведен на цыплятах-бройлерах кросса Росс308 в условиях ООО ПР «Михай-

\begin{tabular}{|c|c|}
\hline Групnа & Особенности кормления \\
\hline Контрольная & Основной рацион (OP) \\
\hline 1 опытная & ОР + ферментный пробиотик в дозе 0,5 кг/т корма \\
\hline 2 опытная & ОР + ферментный пробиотик в дозе 1,0 кг/т корма \\
\hline 3 опытная & ОР + ферментный пробиотик в дозе 1,5 кг/т корма \\
\hline
\end{tabular}

Таблица 2. Состав и питательность комбикормов для цыплят-бройлеров

\begin{tabular}{|c|c|c|}
\hline Компоненты, \% & Комбикорм ПК-5 & Комбикорм ПК-6 \\
\hline Кукуруза & 43,5 & 43,5 \\
\hline Пшеница & 19,5 & 20,0 \\
\hline Жмых подсолнечный & 14,5 & 12,7 \\
\hline Шрот соевый & 10,5 & 14,5 \\
\hline Дрожжи кормовые & 5,5 & - \\
\hline Рыбная мука & 2,5 & - \\
\hline Мясокостная мука & - & 3,0 \\
\hline Жир кормовой & 0,7 & 0,9 \\
\hline Соль поваренная & 0,3 & 0,3 \\
\hline Трикальцийфоссрат & 2,0 & - \\
\hline Обесфторенный фосфат & - & 3,0 \\
\hline Мел кормовой & - & 1,1 \\
\hline Премикс П6-1-89 & 1,0 & 1,0 \\
\hline \multicolumn{3}{|c|}{ В 100 г комбикорма содержалось (\%): } \\
\hline Обменной энергии, МДж & 1,297 & 1,339 \\
\hline Сырого протеина & 23,0 & 21,0 \\
\hline Сырого жира & 6,84 & 6,49 \\
\hline Сырой клетчатки & 4,0 & 4,0 \\
\hline БЭВ & 51,2 & 52,3 \\
\hline Триптофана & 0,23 & 0,21 \\
\hline Лизина & 1,25 & 1,14 \\
\hline Треонина & 0,84 & 0,77 \\
\hline Метионина+цистина & 0,92 & 0,84 \\
\hline Кальция & 1,0 & 1,2 \\
\hline Фосфора & 0,40 & 0,40 \\
\hline Натрия & 0,20 & 0,20 \\
\hline Линолевой кислоты & 1,3 & 1,3 \\
\hline $\begin{array}{l}\text { На } 1 \text { т комбикорма добавлялось } \\
\text { метионина, г }\end{array}$ & 800 & 600 \\
\hline
\end{tabular}

ловский» Пригородного района РСО-Алания, по схеме, представленной в табл. 1.

Из цыплят суточного возраста методом групп-аналогов было сформированы 4 группы: 1 контрольная и 3 опытные, численностью 100 голов в каждой. Продолжительность опыта составила 42 дня.

Цыплят-бройлеров контрольной группы кормили комбикормами, зерновую основу которых составляли ингредиенты местного производства (основной рацион). Птицу опытных групп 1-3 кормили теми же комбикормами, в состав которых дополнительно вводился ферментный пробиотик в дозах 0,5; 1,0 и 1,5 кг/т на протяжении всего периода выращивания.

Нормированное кормление было двухфазным и дифференцировалось в зависимости от возраста цыплят: в возрасте 1-28 дней жизни - полнорационный комбикорм ПК-5; 29-42 дня - полнора- 

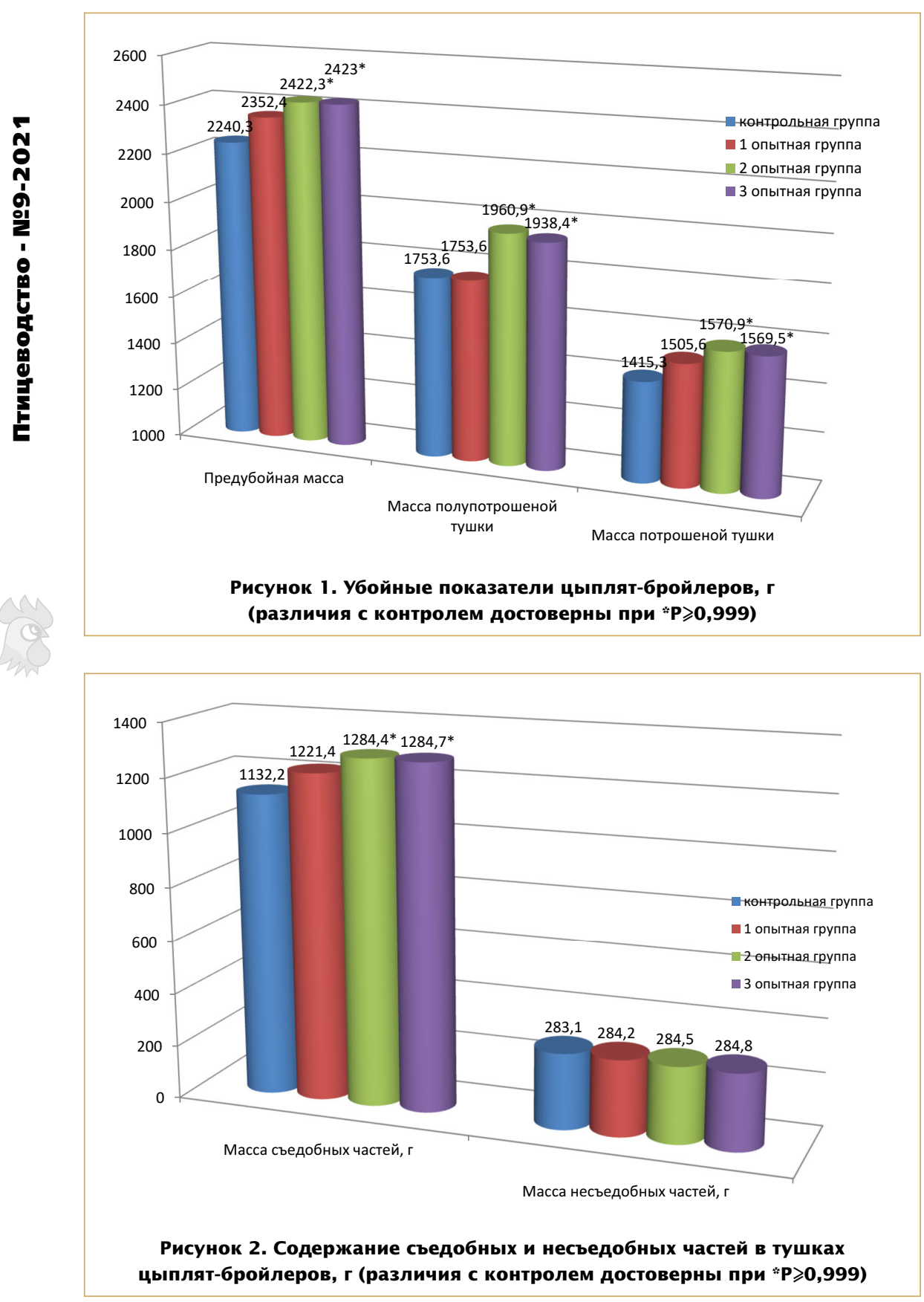

ционный комбикорм ПК-6. Состав комбикормов приведен в табл. 2.

Температурный и световой режимы, влажность воздуха, фронт кормления и поения соответствовали требованиям для данного кросса птицы.

Для проведения контрольного убоя из каждой группы отобрали по 5 голов, средних по живой массе и упитанности. Категорию тушек определяли в соответствии с ГОСТ 25391-82. тательным веществам, в том числе и по биологически активным.

Убойные качества играют важную роль для оценки эффективности выращивания бройлеров. Основными показателями убойных качеств являются: предубойная масса, масса полупотрошеной и потрошеной тушки, изученные нами в ходе контрольного убоя птицы.

Для увеличения этих показателей основную роль играет кормление. Для определения влияния изучаемого ферментного пробиотика на убойные показатели бройлеров был произведен контрольный убой, результаты которого частично приведены на рис. 1 и 2 и в табл. 3.

По результатам контрольного убоя было установлено, что бройлеры всех опытных групп по убойным показателям превзошли своих аналогов из контрольной группы. В первую очередь, это касается 2 и 3 опытных групп, в которых повышение предубойной живой массы, а также массы полупотрошеной и потрошеной тушек, в сравнении с контрольной группой, было статистически достоверным. Так, средняя предубойная живая масса в этих двух группах повысилась соответственно на 182,0 и 182,7 г $(\mathrm{P} \geq 0$,999).

Масса полупотрошеной тушки была максимальной во 2 опытной группе - на 96,0 и 22,5 г больше, чем в 1 и 3 опытных группах, и на 207,3 г больше $(P \geq 0,999)$, чем в контрольной группе. Средний показатель массы полупотрошеной тушки, полученный в 3 опытной группе, также достоверно превосходил показатель контрольной группы на 184,8 г. Средняя масса тушек при полном потро- 


\begin{tabular}{|c|c|c|c|c|}
\hline \multirow{2}{*}{ Показатель } & \multicolumn{4}{|c|}{ Группа } \\
\hline & контрольная & 1 опытная & 2 опытная & 3 опытная \\
\hline Всего тушек, шт. & 93 & 95 & 96 & 96 \\
\hline $\begin{array}{l}\text { Количество тушек } 1 \\
\text { категории, шт. }\end{array}$ & 69 & 74 & 78 & 77 \\
\hline$\%$ & 74,2 & 77,9 & 81,3 & 80,2 \\
\hline $\begin{array}{l}\text { Количество тушек } 2 \\
\text { категории, шт. }\end{array}$ & 24 & 21 & 18 & 19 \\
\hline$\%$ & 25,8 & 22,1 & 18,7 & 19,8 \\
\hline
\end{tabular}

шении также была максимальной во 2 опытной группе: достоверно выше, чем в контрольной группе, на 155,6 г. Немногим меньше на 154,2 г - было превосходство показателя 3 опытной группы над контрольной.

Представляется интересным расчет относительных показателей убоя. Установлено, что выход полупотрошеной тушки от предубойной массы в контрольной группе составил 78,3\%, а выход потрошеной тушки - 63,2\%. Максимального выхода полупотрошеной и потрошеной тушек удалось добиться при использовании в кормлении бройлеров повышенных доз ферментного пробиотика. Выход полупотрошеной тушки во 2 и 3 опытных группах достиг 80, 1 и 80,0\% соответственно, а потрошеной - 64,9 и 64,8\%.

Для более полной оценки влияния ферментного пробиотика на мясные качества цыплят-бройлеров потрошеные тушки во всех группах были разделены на сьедобные и несьедобные части, по соотношению которых рассчитали коэффициент мясности. Как видно из рис. 2, во 2 и 3 опытных группах было выделено достоверно больше съедобных частей, чем в контрольной группе, при том, что по содержанию в тушках несъедобных частей существенных различий между всеми группами не наблюдалось. Благодаря уве- личению массы сьедобных частей в тушках цыплят-бройлеров 2 и 3 опытных групп на 152,2 и 152,5 г соответственно, коэффициент мясности в этих группах был увеличен до 4,52 и 4,51, в то время ставил всего 4,00. В 1 опытной группе коэффицциент мясности занимал промежуточное положение между контрольной и остальными опытными группами - 4,30.

В дополнение все тушки, полученные В результате контрольного убоя во всех группах, были распределены на категории по соответствующему ГОСТу (табл. 3). Из 93 тушек, полученных в результате убоя бройлеров контрольной группы, сохранившихся к концу опыта, 69 штук или 74,2\% были отнесены к первой категории, а 24 или 25,8\%ко второй категории. Благодаря более высокой сохранности поголовья, за счет включения в рацион ферментного пробиотика в дозе 1,0 и 1,5 кг/т корма, во 2 и 3 опытных группах убою были подвергнуты по 96 голов. Из них во 2 опытной группе к первой категории было отнесено 78 штук или $81,3 \%$, а в 3 опытной группе - 77 или $80,2 \%$.

Заключение. Анализируя полученные данные, можно придти к заключению, что для повышения мясных качеств цыплятбройлеров целесообразно при как в контрольной группе он со- их выращивании вводить в комбикорма, приготовленные из ингредиентов местного производства, ферментный пробиотик в количестве 1,0 кг на 1 т корма. Доза 1,5 кг/т не дает существенного положительного эффекта по сравнению с дозой 1,0 кг/т, поэтому ее использование нецелесообразно.

\section{Литература}

1. Анчиков В. Эфрфективность применения ферментов в птицеводстве / В. Анчиков, С. Кислюк // Комбикорма. - 1999. - №2. - С. 30-31.

2. Бугай И.С. Продуктивность бройлеров при добавлении фермента в комбикорма с зерном сорго / И.С. Бугай, С.И. Кононенко // Сб. науч. тр. Ставропольского НИИ жив-ва и кормопрва. - 2014. - Т. 2. - №7. - С. 22- 26.

3. Егоров И. Роль ферментных препаратов в повышении эффективности комбикормов, содержащих трудногидролизуемые компоненты / И. Егоров, А. Егорова // Птицефрабрика. 2009. - № 4. - С.16-38.

4. Калоев Б.С. Применение биологически активных препаратов как способ улучшения использования бройлерами питательных веществ рациона / Б.С. Калоев, М.С. Гурциева // Птицеводство. - 2020. - №3. - С. 25-30. 5. Калоев Б.С. Возможности улучшения мясных качеств цыплят-бройлеров / Б.С. Калоев, М.О. Ибрагимов, 3.В. Псхациева // Вестник Ульяновской ГСХА. - 2017. - №3. - С. 118.

6. Колесникова И.А. Морфологические и биохимические показатели крови цыплят-бройлеров при скармливании пробиотика и микронутриента // Вестник мясного скотоводства. - 2017. - №2. - С.147-155.

7. Ногаева В.В. Эффективность применения кормовой добавки в кормлении птицы // Вестник науч. тр. мол. уч., асп. и магистр. Горского ГАУ. 2016. - C. 102-104. 
8. Севостьянова О.И. Нутрицевтическая полноценность рационов цыплят-бройлеров как основа высокой продуктивности кроссов / О.И. Севостьянова, В.А. Оробец, Е.С. Кастарнова, А.В. Серов // Вестник АПК Ставрополья. - 2018. - №3. - С. 21-25.

9. Темираев Р. Пробиотики и ферментные препараты в рационах цыплят /
Р. Темираев, В. Гаппоева, Н. Гагкоева // Птицеводство. - 2009. - №4. - С. 20-21.

10. Чиков А.Е. Использование ферментных препаратов в животноводстве / А.Е. Чиков, С.И. Кононенко, Л.Н. Скворцова, А.Н. Ратошный. Краснодар, 2008. - С. 76-78.

11. Kaloev B.S. Effect of enzyme preparations "Sanzaym", "Sanfayz 5000" and lecithin on the quality of broiler meat / B.S. Kaloev, M.O. Ibragimov, L.H. Albegova, F.M. Kulova, Z.A.Kadzaeva, B.B. Nogaeva // J. Livest. Sci. - 2020. - V. 11 . P. 143-148.

\section{Для контакта с автором:}

Калоев Борис Сергеевич

E-mail: bkaloev@yandex.ru

\section{The Improvement of Meat Productivity in Broilers Fed an Enzymatic Probiotic}

Kaloyev B.S.

Gorsky State Agrarian University

Summary: The effects of an enzymatic probiotic in the diets on meat productivity in broilers were studied on 4 treatments of Ross-308 broilers (100 birds per treatment, 1-42 days of age). Control treatments was fed grower (1-28 days of age) and finisher (29-42 days) locally produced compound feeds based on corn, wheat, sunflower cake, and soybean meal; similar diets for treatments 1-3 were additionally supplemented with different doses of the probiotic (500; 1,000 and 1,500 ppm, respectively). Live bodyweight at slaughter, weights and yields of semi-eviscerated and eviscerated carcass, edible and non-edible parts, distribution of the carcasses according to trade categories were determined. The best values for almost all these parameters were found in treatment 2; further increase of the dose of the probiotic to 1,500 ppm did not result in considerable improvements in these traits and hence the dose of 1,000 ppm could be considered optimal for broiler diets.

Keywords: broilers, enzymatic probiotic, live bodyweight at slaughter, carcass yield, categories of carcass quality.

\section{Подмоскобная птищефабрика начала запускать итичники после реконструки,и}

Торжественное открытие предприятия пройдет 6 начале октября.

Орехово-Зуебская птицефабрика «Элинар-Бройлер» открыла после реконструкиии сразу шесть сбоих птичников. Об этом сообщается на официальном сайте правительства Московской области.

«Одно из крупнейших предприятий по произбодству инкубационного яйца и мяса птиць - «пицефабрика «Элинар-Бройлер» завершает реконструкцию племенного птицерепродуктора Малодубенский. Пробедены босстанобительные работы птицерабрики 1 очереди, бключающие ремонт зданий 6 птичников. Дата запуска и торжественного открытия запланирована на начало октября текущего года». - Сергей Воскресенский, министр сельского хозяйства и продовольствия Московской области.

Помимо реконструкции помещений птицефабрика также получит новое оборудование. Его установка завершится 6 ближайшее время. Всего планируется отремонтировать 29 птичников.

Общий объем средств затраченных на восстановление птицесрабрики состабил порядка 680 миллионов рублей. 